\title{
Responding To State Sales Tax Laws For Online Retailers - A Case Study Of Amazon And The States
}

Ross A. Malaga, Montclair State University, USA

\begin{abstract}
As state budgets have come under increasing pressure, many states have enacted so called "Amazon taxes" that seek to have large online retailers collect state sales tax. States are attempting to expand the concept of nexus to include marketing affiliates and corporate subsidiaries. Amazon and other large retailers have reacted in different ways depending on the state and the specific legislation. This paper discusses the potential impact of these new laws and how both states and online retailers have dealt with the issues involved.
\end{abstract}

Keywords: State Sales Taxes for Online Retailers; Amazon Taxes

\section{INTRODUCTION}

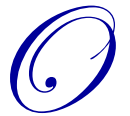

ver the past few years state budgets have suffered major shortfalls. In an effort to partially close their budget gaps many states have passed laws that require large online retailers to charge state sales tax to its customers (so called Amazon Taxes). Traditionally, online retailers only collected sales tax for states in which they had a physical presence. The new state laws seek to broaden the definition of a physical presence by targeting those online retailers that use affiliates to market their products or who have other types of business activity, such as warehouses or product developers, within the state.

The collection of sales tax from online retailers is a major problem for states and retailers. According to a recent Wall Street Journal report the amount of lost tax revenue to the states is estimated at $\$ 10.1$ to $\$ 11.3$ billion annually (Woo, 2011). The largest online retailer, Amazon.com, has indicated in recent SEC filings that a new online sales tax collection law in Texas could significantly impact its earnings (Amazon, 2011). Traditional retailers, those with physical stores, believe they are disadvantaged in that they are required to charge sales tax, whereas online retailers are not.

The goals of this paper are twofold. First, is seeks to examine the impact of these new laws on all parties concerned; state governments, online retailers, and affiliate marketers. Second, by analyzing multiple case studies, this paper attempts to determine how states and online retailers should best approach this issue.

\section{BACKGROUND}

In order to fully understand this new phenomenon a background on affiliate marketing, sales tax, and use tax is required.

\section{AFFILIATE MARKETING}

Affiliate marketing is an e-commerce business model in which an online retailer agrees to pay a commission to individuals or businesses that send it traffic that leads to an action (usually a sale) (Malaga 2007). Thus the affiliate model is often referred to as cost-per-action (CPA). Affiliate marketers use special links to a merchant's Website that enable the merchant to track the traffic and sales back to the affiliate and ensure they receive credit for any action taken. 
Commissions are usually paid on a sale, but some merchants will also pay for each lead. In addition, commission rates vary widely. For example, commissions for physical products typically range from 5-20\%. However, commissions for information goods (e-books and software) are normally in the 40-60\% range.

Some examples of how affiliate marketing works include:

- $\quad$ an individual recommending a specific product via Facebook includes an affiliate link to the product

- a non-profit organization asks its members to click on a link on the organization's Website when making purchases from certain vendors

- $\quad$ a business develops a review site or mobile app that shows the best deals of the day - the deals include an affiliate link to the merchant's site.

In each of these circumstances the entity providing the link (individual, non-profit, business) receives a commission from the merchant when a sale is made.

Affiliate programs are run using one of two main models. In the first model the merchant runs its affiliate program in house. The merchant includes the ability to generate affiliate links and track them through the checkout process. Under this model the merchant pays affiliates directly, usually on a monthly basis. Many large online retailers, such as Amazon.com, use this model.

The second model uses a third party, called an affiliate network (examples include Commission Junction and ShareASale), to generate affiliate links, track sales, and pay affiliates. These third party companies serve as a trusted intermediary between the merchant and the affiliate. Merchants register with the affiliate network and add code to their checkout process that allows the network to track affiliate sales. Affiliates register with the network and then must also register with specific merchants in the network (merchants have the right to reject an affiliate if the affiliate's Website or marketing methods are not aligned with the merchants business focus or marketing goals). The affiliate network provides the link to the affiliate, tracks sales, and pays the affiliate directly. The affiliate network is paid by the merchant - usually a setup fee and an ongoing percentage of affiliate sales.

The exact size of affiliate marketing activity is difficult to determine. Many public online retailers, such as Amazon.com, include payouts to affiliates as part of their overall marketing expenses. Therefore, the total amount of revenue online retailers received through their affiliates cannot easily be determined. However, ValueClick is a public company that owns one of the largest affiliate networks (Commission Junction). According to its recent SEC filings the company generated $\$ 124$ million in revenue during FY 2010 (ValueClick, 2011). It should be noted that this revenue actually represents fees paid by the merchants, not affiliate payouts.

\section{SALES AND USE TAX}

Merchants with a physical presence in a jurisdiction (state, county, city, etc.) are required to collect sales tax on items they sell (certain items may be exempt from sales tax). For a traditional bricks and mortar retail store it is easy to determine where they have a physical presence and exactly what sales taxes it needs to collect. However, for businesses that sell products primarily online the collection of sales tax can be problematic. By some estimates there are over 7000 different sales tax rates in the United States (Sales Tax Clearinghouse).

Take, for example, New York City (NYC). In NYC the sales tax rate is $4.5 \%$ on most products. However, merchants must also add the New York State sales tax rate of $4 \%$ and the Metropolitan Commuter Transportation District (MCTD) surcharge of $0.375 \%$. So, the total sales tax that should be collected is $8.875 \%$. To confuse the matter further clothing and footwear purchases of less than $\$ 110$ are exempt from New York City sales tax. In addition, from April 1, 2011 through March 31, 2012 clothing and footwear purchases of less than $\$ 55$ per item are exempt from the state sales tax and the MCTD surcharge. But on April 1, 2012 the exemption minimum increases back to $\$ 110$ (NYC Finance).

These types of exemptions, based on type of product and time, are repeated in thousands of jurisdictions through the United States. For online merchants keeping up with all of these sales tax regulations can be difficult and expensive. In addition, the ability to not charge sales tax provides many online retailers a price advantage. 
The U.S. Supreme Court has made two significant rulings on the collection of sales tax. In the first case, Scripto vs. Carson (Clark, 1960) the state of Florida attempted to collect sales tax from the Scripto pen company that was located in Georgia. However, Scripto made use of commissioned salespeople to sell their products to customers in Florida. The company argued that as the salespeople were independent contractors they did not constitute a physical presence in Florida. The Court, in its ruling against Scripto, stated that there was no "constitutional significance" between employees and independent contractors. This ruling is important for the purposes of our discussion as affiliates can be regarded as independent contractors working on behalf of the online merchant.

The second important Supreme Court ruling is the 1992 case Quill vs. North Dakota. Quill was an office supply company that sold its products via a mail order catalog. North Dakota attempted to collect sales tax from Quill for purchases made by North Dakota residence. The Court ruled that Quill did not have "nexus" in North Dakota and therefore no sales taxes were due. The Court defined nexus as a physical presence in the state - such as an office, warehouse, or employees (Stevens, 1992). Including employees in this definition can become important as more people telecommute. For example, a programmer working for an online retailer might live and work anywhere. Using the definition of nexus provided by the Court that one employee could trigger the requirement that the online merchant charge sales tax in the employee's state.

\section{USE TAX}

A person from one state who makes a non-taxable purchase in another, may be required to pay a use tax to their own state. For example, if a person in New Jersey travels to New York to purchase a product that is not taxed in New York, but is taxed in New Jersey, that person would pay a use tax in New Jersey. In theory, purchases made online or via mail order are subject to use tax - which would largely eliminate the state's revenue problems. However, in reality very few individuals ever report or pay use taxes. According to a recent report (Klein, 2011) California loses $\$ 1$ billion annually from unreported use taxes on online and mail order purchases made by state residents.

\section{A REVIEW OF CURRENT STATE LAWS AND AMAZON'S RESPONSE}

Amazon does collect sales tax in a number of states in which it has a physical presence. These include Washington (where Amazon has its headquarters), Kansas (call center), North Dakota (call center), and Kentucky (returns processing center). In addition, Amazon does collect sales tax in New York pending the outcome of litigation.

As of late 2011, a number of states had passed laws requiring large online retailers to collect sales tax.

\section{New York}

New York State kicked off the sales tax battle in 2008 when it passed NY Tax Law 1101(b)(8)(vi) the so called "Amazon Tax". This law required online merchants who receive more than $\$ 10,000$ in sales per year from New York state affiliates to charge sales tax to customers in the state. It should be noted that Amazon is not the only online merchant that would be covered by the law - Overstock.com for example has also been impacted.

Amazon immediately sued the state (this suit was joined by Overstock.com) (Amazon.com, LLC vs. New York State Department of Taxation, 2010). The original trial judge dismissed the case. Amazon quickly appealed and a ruling was handed down on November 4, 2010. In that ruling the appeals court sent the case back down for trial. In doing so the court stated that the main issue in the case revolves around the concept of solicitation. If affiliates are actively soliciting business on behalf of Amazon (Overstock) then their actively likely constitutes nexus in the state. However, if affiliates are merely advertising then it likely does not constitute nexus (Amazon.com, LLC vs. New York State Department of Taxation, 2010). The case is still pending and any verdict it likely to be appealed (probably up to the Supreme Court).

Amazon is collecting sales tax from New York customers and depositing it in an escrow account while the case is ongoing (Mitchell, 2011). Overstock has taken a different approach - choosing to remove New York based affiliates entirely. 


\section{Arkansas, Connecticut, Illinois, North Carolina, Rhode Island, Vermont}

This group of states has passed laws similar to the New York legislation. It should be noted that Vermont's law only goes into effect when 15 other states pass similar laws. Amazon's response to these laws has been to cancel its affiliate programs in these states.

\section{Colorado}

In 2010 Colorado passed a law that would require online retailers to send its customers an annual notice of how much sales tax (use tax) they owed. In addition, the law allows the Department of Revenue to request a list of what individual Colorado residence spend on an annual basis from large online retailers (Engleman, 2010). Amazon canceled its affiliate program in Colorado in response to this legislation. The Direct Marketing Association (DMA) brought a lawsuit against the state. In January 2011 a Federal judge ruled on Constitutional grounds that the DMA was likely to prevail and issued a temporary injunction preventing the state from enforcing the law (Blackburn, 2011).

\section{Texas}

Texas has taken a number of paths toward collecting sales taxes from Amazon. In September 2010 the Texas Comptroller sent Amazon a bill for \$269 million in uncollected sales tax (the amount includes interest and penalties). The Comptroller claims that Amazon has a physical presence, a distribution center, in the state. However, the distribution center is owned by an Amazon subsidiary, not Amazon directly.

During 2011 the Texas legislature passed a measure that would establish nexus for any company that owns more than 50 percent of a subsidiary with a physical presence in the state. The legislation was vetoed by the governor, but legislators prepared to attach it to a must pass fiscal bill.

In the midst of the political battle in Texas Amazon offered the state a deal. The company would invest $\$ 300$ million in distribution centers in the state (employing about 6,000 people) if the state would allow Amazon to not collect sales tax for four and a half years (Ramsey, 2011). Actually, Amazon would agree to print the amount of sales tax owed on receipts for Texas customers and the customer would need to remit the tax to the state (essentially turning it into a use tax).

\section{South Carolina \& Tennessee}

In South Carolina the legislature initially defeated a bill that would have provided a five year sales tax exemption for Amazon (and other large online retailers). However, after Amazon threatened to cancel building a proposed distribution center (investing about $\$ 125$ million and creating about 2,000 new jobs) in the state the bill passed. Under the legislation Amazon would provide language on South Carolina customer receipts indicating they owed sales (use) tax and linking to the South Carolina Department of Revenue (Morrow, 2011).

Amazon's experience in Tennessee closely follows the South Carolina model. Under a deal there Amazon would be required to begin collecting sales tax on January 1, 2014. In exchange, Amazon agreed to open two distribution centers in the state - employing about 1,500 to 2,000 workers (Angotti, 2011).

\section{California}

During 2011 California became the latest battleground in the Amazon sales tax debate. In an effort to close its budget gap the state implemented a law (ABX1 28) that would require online retailers with affiliates, offices, workers, or other ties in the state to collect California sales tax. It was believed that this measure would raise \$200 million in tax revenue for the state (Pepitone, 2011).

Amazon had a two-fold response to the sales tax measure. First, it threatened to cancel its affiliate program in the state. This would impact Amazon's approximately 10,000 California affiliates. Second, it wrote a 
referendum and collected enough signatures to get it placed on the ballot - essentially allowing California voters to decide.

In September, 2011 California repealed the sales tax bill (AB 155). Basically, Amazon struck a deal with the state exempting them (and other online retailers) from collecting sales tax until September 15, 2012. On that date the sales tax law would go into effect, unless the federal government passes a national online sales tax law before then (Wood, 2011).

\section{DISCUSSION}

The ways in which Amazon has responded to the various state sales tax initiatives is revealing. In general, the responses can be broken into four categories.

First, Amazon (and other large online retailers such as Overstock and affiliate networks like Commission Junction) has determined that in some states it is more cost effective to cancel their affiliate program than to collect sales tax or spend the time and money on litigation. This seems to be primarily true for smaller states in which Amazon is not likely to have as many affiliates. Unfortunately, canceling affiliate programs is a losing proposition for all concerned. Affiliates in affected states obviously lose an income stream. The states actually lose tax revenue as affiliates no longer pay income tax on their affiliate earnings. And, the online retailers lose as they are no longer able to leverage affiliates in these states.

Second, in some states (South Carolina and Tennessee) Amazon has chosen to negotiate - exchanging sales tax breaks for the creation of distribution centers (and the jobs that go along with them). This approach seems to be good for Amazon, as it can pick the states it wants to negotiate with. In addition, Amazon seems to have the upper hand in these negotiations as it is not currently collecting sales tax and can simply choose to cancel its affiliate program and/or shut down distribution centers if the state refuses to negotiate or Amazon does not agree with the terms. However, this approach does not help other online retailers (or affiliate networks), most of whom do not have the negotiating power of Amazon. In addition, these deals must be negotiated on a case-by-case basis so the solution is not scalable.

In California, the state, not Amazon, seemed to have the upper hand in negotiations. In that case the law not only included affiliates, but also subsidiaries. Amazon owns a subsidiary called Lab126 (www.lab126.com) located in Cupertino, CA (in the heart of Silicon Valley). This subsidiary develops Amazon's popular Kindle line of ebook readers and tablet computers. While Amazon could (and did) threaten to cancel its affiliate program in California, it would likely be much more difficult for the company to move Lab126 or the development work out of the state. This forced Amazon to agree to begin collecting California sales tax within a year.

Third, in New York Amazon has chosen to litigate. This makes sense as New York was the first state to pass an affiliate sales tax law. In addition, the legal basis for these laws comes from the two main Supreme Court rulings (Scripto and Quill). The Appeals Court in NY has ruled in favor of Amazon and framed the main issues in the case. In Colorado (where the DMA filed suit) the court ruled based on the Commerce Clause of the Constitution. As these issues are working their way through various state courts, it seems likely that in the end these cases may be decided by the U.S. Supreme Court.

Finally, there have been for many years, various proposals put forward at the federal level to impose a sales tax on online retailers (and in some cases catalog merchants). The latest effort is called the "Main Street Fairness Act" sponsored by Sen. Dick Durban (D-IL). This law would allow states to require large online retailers to collect state sales tax under certain conditions. The main condition is that the state must pass legislation implementing the Streamline Sales Tax and Use Tax Agreement (SSUTA). The SSUTA is an effort sponsored by the National Governor's Association to simplify sales tax definitions and collection. For example, the SSUTA requires participating states to enact uniform product definitions. The idea is to eliminate conflicts where, for example, one state defines cookies as a food and another defines cookies as candy (subjecting cookies to different sales tax rates). As of late 2011, 24 states have implemented the SSUTA (New Rules Project). 
Amazon has publicly endorsed the "Main Street Fairness Act". In a recent letter to Sen. Dick Durban, Amazon.com, Inc's Vice President for Global Public Policy Paul Misener said: “Amazon.com has long supported a simple, nationwide system of state and local sales tax collection, evenhandedly applied to all sellers, no matter their business model, location, or level of remote sales. To this end, I am writing to thank you for your bill that would allow states that sufficiently simplify their rules to require collection of sales tax by out-of-state sellers (Misener, 2011)." In fact, Amazon would clearly like this bill to pass quickly as it would negate its deal with California. The bill has not moved toward a vote as of the end of 2011.

\section{CONCLUSIONS}

As states' tax revenues have decreased over the past few years, many states have looked for new ways to balance their budgets. A number of states have targeted large out of state online retailers as a potential revenue source - passing so called "Amazon" taxes. At first glance these laws are a rational response by states facing budget shortfalls. However, in many cases these taxes might actually hurt tax revenues. The main response to these taxes by Amazon (and other large online retailers and affiliate networks) has been to cancel their affiliate programs in those states that have passed these laws. This deprives the states with both the potential sales tax revenue and the income tax that might be earned by affiliates living in that state.

In the end it is likely that this issue will be decided not state-by-state, but at the federal level. While the "Main Street Fairness Act" has not moved forward in the current Congress, with support from both traditional retailers and Amazon there is the possibility it might become law sometime in the near future. In the meantime Amazon's lawsuit in New York and the DMA lawsuit in Colorado are moving through the courts and one or both cases are likely to end with the Supreme Court down the road.

\section{AUTHOR INFORMATION}

Ross A. Malaga is a professor of management information systems, School of Business, Montclair State University, Montclair, New Jersey, USA. He holds a Ph. D. in Information Systems from George Mason University, a MS, Information Systems from George Washington University, and a BA in Political Science from American University, USA. His Areas of Expertise include E-Commerce and Internet Marketing, Search Engine Optimization, and Webbased Teaching and Learning. He currently serves on the editorial review boards of Information Resources Management Journal, the Journal of Electronic Commerce in Organizations and the International Journal of Mobile and Blended Learning. E-mail: Malagar@mail.montclair.edu

\section{REFERENCES}

1. Angotti, D. (2011). "Internet sales tax: Tennessee \& Amazon reach agreement", Search Engine Journal, October 7, 2011. Retrieved January 4, 2012 from http://www.searchenginejournal.com/tennessee-amazon$\underline{\text { sales-tax/34608/ }}$

2. Amazon.com (2011). Form 10-K for the fiscal year ended December 31, 2010. Retrieved January 4, 2012 from http://yahoo.brand.edgar-online.com/DisplayFiling.aspx?dcn=0001193125-11-016253

3. Amazon.com, LLC v New York State Department of Taxation and Finance (2010). Retrieved January 4, 2012 from http://www.courts.state.ny.us/reporter/3dseries/2010/2010_07823.htm

4. Blackburn, R.E. (2011). "Civil Case No. 10-cv-01546-REB-CBS The Direct Marketing Association, Plaintiff, v.ROXY HUBER, in her capacity as Executive Director, Colorado Department of Revenue, Order Granting Motion for Preliminary Injunction", Retrieved on January 4, 2012 from http://www.thedma.org/segment/segmentfiles/catalogers/20110126OrderGrantingPI.pdf

5. $\quad$ Clark, T.C. (1960). "Scripto, Inc. v. Carson”, U.S. Supreme Court, 362 U.S. 207.

6. Engleman, E. (2010). "Colorado law sets new rules for Amazon, other online retailers", TechFlash Amazon Blog, March 2, 2010, Retrieved January 4, 2012 from http://www.techflash.com/2010/03/colorado_law_adds_new_twist_to_amazon_sales_tax_debate.html

7. Klein, K.E. (2011). “Use-tax law requires some firms to register”, Los Angeles Times, May 16, 2011, Retrieved January 4, 2012 from http://articles.latimes.com/2011/may/16/business/la-fi-smallbiz-qa$\underline{20110516}$ 
8. Malaga, R.A. (2007). "The New Marketing Intermediaries - A multiple case study of three new E-business models", Journal of Academy of Business and Economics, Vol. 7, No. 1, 2007.

9. Misener, P. (2011). Letter to Senator Dick Durban dated July 29, 2011. Retrieved January 4, 2012 from http://durbin.senate.gov/public/index.cfm/files/serve?File_id=a92e4a69-dba4-4aba-97a7-1a8c413ab206

10. Mitchell, D. (2011). “Will California's 'Amazon tax' cause an affiliate exodus?”, CNN Money, June 29, 2011, Retrieved January 4, 2012 from http://tech.fortune.cnn.com/2011/06/29/california-passes-amazontax-amazon-pulls-plug-on-affiliates/

11. Morrow, M. (2011), "No sales tax for Amazon in SC", TN Report, May 31, 2011. Retrieved January 4, 2012 from http://www.tnreport.com/2011/05/no-sales-tax-for-amazon-in-sc/

12. New Rules Project. "Main Street Fairness Act”. Retrieved January 4, 2012 from http://www.newrules.org/retail/rules/internet-sales-tax-fairness/main-street-fairness-act

13. NYC Finance. "Business and Excise Taxes". Retrieved January 4, 2012 from http://www.nyc.gov/html/dof/html/business/business_tax_nys_sales.shtml

14. Pepitone, J. (2011). “Amazon: No California sales tax collection til 2012”, CNN Money, September 9, 2011. Retrieved January 4, 2012 from http://money.cnn.com/2011/09/08/technology/amazon_california_sales tax/index.htm

15. Ramsey, R. (2011). “Let's make a deal, Amazon tells Texas”, New York Times, June 23, 2011. Retrieved January 4, 2012 from http://www.nytimes.com/2011/06/24/us/24ttramsey.html

16. Sales Tax Clearinghouse. Retrieved January 4, 2012 from http://thestc.com/FAQ.stm

17. Stevens, J.P. (1992). "Quill Corporation, Petitioner V. North Dakota”, U.S. Supreme Court, No. 91-194, May 26, 1992.

18. Valueclick, Inc. (2011). Form 10-K for the fiscal year ended December 31, 2010. Retrieved January 4, 2012 from http://ir.valueclick.com/financials.cfm

19. Woo, Stu (2011). “Amazon battles states over sales tax”, Wall Street Journal, August 3, 2011, Retrieved January 4, 2012 from http://online.wsj.com/article/SB10001424053111904772304576468753564916130.html\#project\%3DAMA ZON110803\%26articleTabs\%3Darticle

20. Wood, R.W. (2011). "Amazon tax: Good, bad, and ugly", Forbes, September 24, 2011. Retrieved January 4, 2012 from http://www.forbes.com/sites/robertwood/2011/09/24/amazon-tax-good-bad-and-ugly/ 


\section{$\underline{\text { NOTES }}$}

